Prosiding Seminar Nasional Teknologi Informasi dan Kedirgantaraan : Transformasi Teknologi untuk Mendukung Ketahanan Nasional, Yogyakarta, 13 Desember 2018

SENATIK 2018, Vol. IV, ISBN 978-602-52742-0-6

DOI: http://dx.doi.org/10.28989/senatik.v4i0.233

\title{
THE PERFORMANCE OF SAVONIUS WINDMILL WITH GUIDE VANE
}

\section{Budi Sugiharto}

Teknik Mesin Universitas Sanata Dharma Yogyakarta

Kampus III, Paingan, Maguwoharjo, Depok, Sleman

Email :sugih@usd.ac.id

\begin{abstract}
The conventional Savonius windmill performance produces a power coefficient of 15\%. The addition of a guide vane aims to improve performance.This paper aims to observed the performance of Savonius windmills with 16 guide vanes with variations in the guide vane angle of $30^{\circ}, 45^{\circ}$ and $60^{\circ}$. The tests are carried out openly with the help of a fan as a source of air flow. The best performance results obtained at wind speeds of $5 \mathrm{~m} / \mathrm{s}$, namely the highest power coefficient occurs on the mill with a $45^{\circ}$ angled guide vane of $24 \%$. The highest torque coefficient is owned by a windmill with a $45^{\circ}$ angular guide vane of $20 \%$ at a rotational speed of $100 \mathrm{rpm}$.
\end{abstract}

Keywords: Savonius windmills, guide vane, power coefficient, torgue coefficient

Abstrak

Kinerja kincir angin Savonius konvensional memiliki nilai koefisien daya sebesar $15 \%$. Penambahan guide vane bertujuan untuk meningkatkan kinerja. Tulisan ini bertujuan untuk mengamati kinerja kincir angin Savonius dengan guide vane berjumlah 16 dengan variasi sudut guide vane $30^{\circ}, 45^{\circ}$ dan $60^{\circ}$. Pengujian dilakukan secara terbuka dengan bantuan kipas sebagai sumber aliran udara. Hasil kinerja terbaik diperoleh pada kecepatan angin $5 \mathrm{~m} / \mathrm{s}$, yaitu koefisien daya tertinggi terjadi pada kincir dengan sudut guide vane $45^{\circ}$ sebesar $24 \%$. Koefisien torsi tertinggi dimiliki oleh kincir angin dengan sudut sudut guide vane $45^{\circ}$ sebesar $20 \%$ pada putaran $100 \mathrm{rpm}$.

Kata kunci : kincir angin Savonius, guide vane, koefisien daya, koefisien torsi

\section{Pendahuluan}

Kebutuhan energi meningkat dengan sangat besar dibanding dengan pertumbuhan penduduk. Sedangkan sumber energi tak terbarukan semakin menipis sehingga diperlukan mencari sumber energi yang terbarukan yang alami dan tidak menambah polusi. Kincir angin merupakan salah satu alat yang menghasilkan energi gerak dari energi terbarukan yaitu angin. Energi gerak hasil dari kincir dapat diubah menjadi gerak yang lain atau dapat pula diubah menjadi energi listrik.

Kincir angin Savonius merupakan salah satu jenis kincir angin poros vertikal yang dapat menerima angin dari segala arah, desain sederhana, tidak berisik, memiliki torsi statis yang besar dan dapat bekerja pada kecepatan angin yang rendah. Kekurangan dari kincir angin Savonius memiliki efisiensi atau koefisien daya yang rendah (15\%) [1] . Berbagai upaya telah dilakukan untuk meningkatkan nilai tersebut. Fujisawa dan Gotoh, menyampaikan bahwa aliran di sekitar kincir Savonius terdiri dari 6 aliran dengan 3 aliran yang bermanfaat dan 3 aliran yang 
mengganggu [2]. Tiga aliran yang bermanfaat yaitu aliran Coanda, aliran overlap dan aliran tarik (dragging flow), sedang tiga aliran yang mengganggu yaitu aliran stagnasi, aliran pusaran pada sudu dorong dan aliran pusaran pada aliran pada sudu balik. Altan et al, menyampaikan kincir Savonius dengan dua plat pengarah, panjang plat pengarah $l_{1}=45 \mathrm{~cm}$ bersudut $\alpha=15^{\circ}$ dan $1_{2}=$ $52 \mathrm{~cm}$ berudut $45^{\circ}$ diperoleh koefisien daya sebesar 38,5\%[3, 4, 5]. Sugiharto et al, meneliti kinerja kincir angin Savonius dengan penambahan pengarah bersudut $45^{\circ}$ dengan variasi jumlah pengarah 4, 8 dan 16. Hasil terbaik diperoleh pada kincir dengan pengarah berjumlah 16 , koefisien daya meningkat $33 \%$ dari kincir tanpa pengarah [6].

Tujuan penelitian ini mengamati perubahan kinerja yang terjadi bila sudut guide vane mengalami perubahan. Perbedaan sudut pengarah yang diamati yaitu $30^{\circ}, 45^{\circ}$ dan $60^{\circ}$. Sedangkan kinerja yang diperhitungkan meliputi koefisien daya dan koefisien torsi.

\section{Metodologi Penelitian}

Kincir angin Savonius dibuat dari PVC 8 inch yang dibelah menjadi 2 dan disusun seperti pada Gambar 1 dengan ukuran diameter kincir $410 \mathrm{~mm}$, tinggi $410 \mathrm{~mm}$ dan tebal end plat $4 \mathrm{~mm}$.

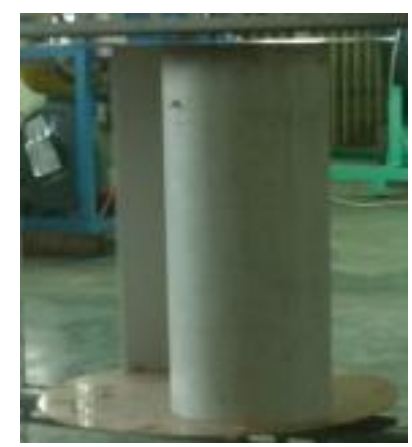

Gambar 1. Kincir angin Savonius

Guide vane dari akrilik dengan ketebalan $5 \mathrm{~mm}$ dan panjang $150 \mathrm{~mm}$ berjumlah 16 diletakkan mengelilingi kincir Savonius, ditunjukkan pada Gambar 2. Guide vane yang digunakan dengan variasi sudut $30^{\circ} .45^{\circ}$ dan $60^{\circ}$ ditunjukkan pada Gambar $3 \mathrm{a}$, b dan c.

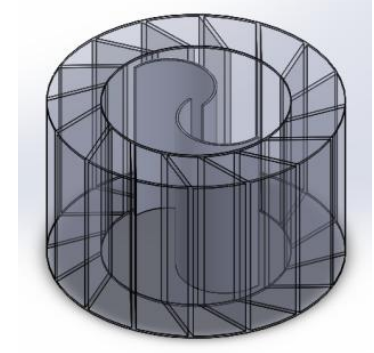

Gambar 2. Susunan guide vane mengelilingi kincir Savonius 


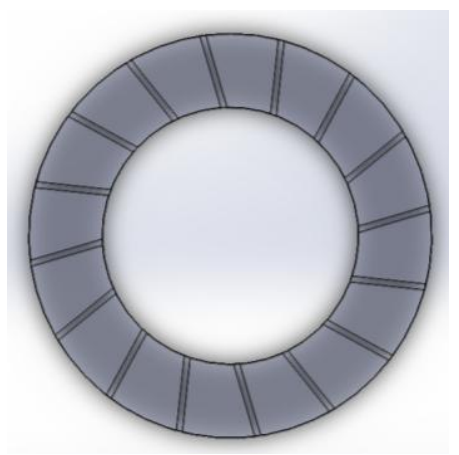

a.

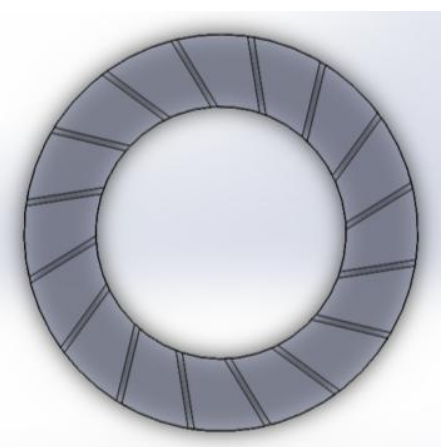

b.

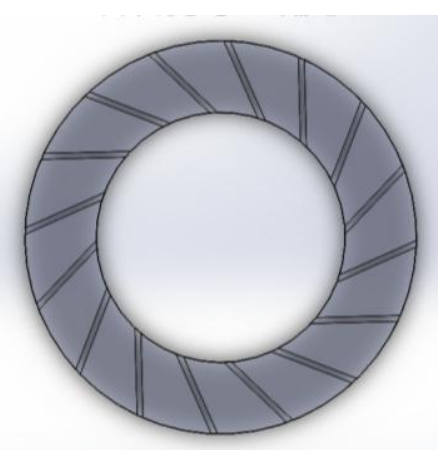

c.

Gambar 3. Guide vane, a. Sudut $30^{\circ}$, b. Sudut $45^{\circ}$, c. Sudut $60^{\circ}$

Kincir Savonius dengan perangkat pengukur gaya pengereman diletakkan di depan fan dengan jarak $2000 \mathrm{~mm}$. Pengukur kecepatan angin (anemometer) diletakkan diantara kincir dengan fan berjarak $1500 \mathrm{~mm}$ dari fan, seperti diperlihatkan pada Gambar 4.

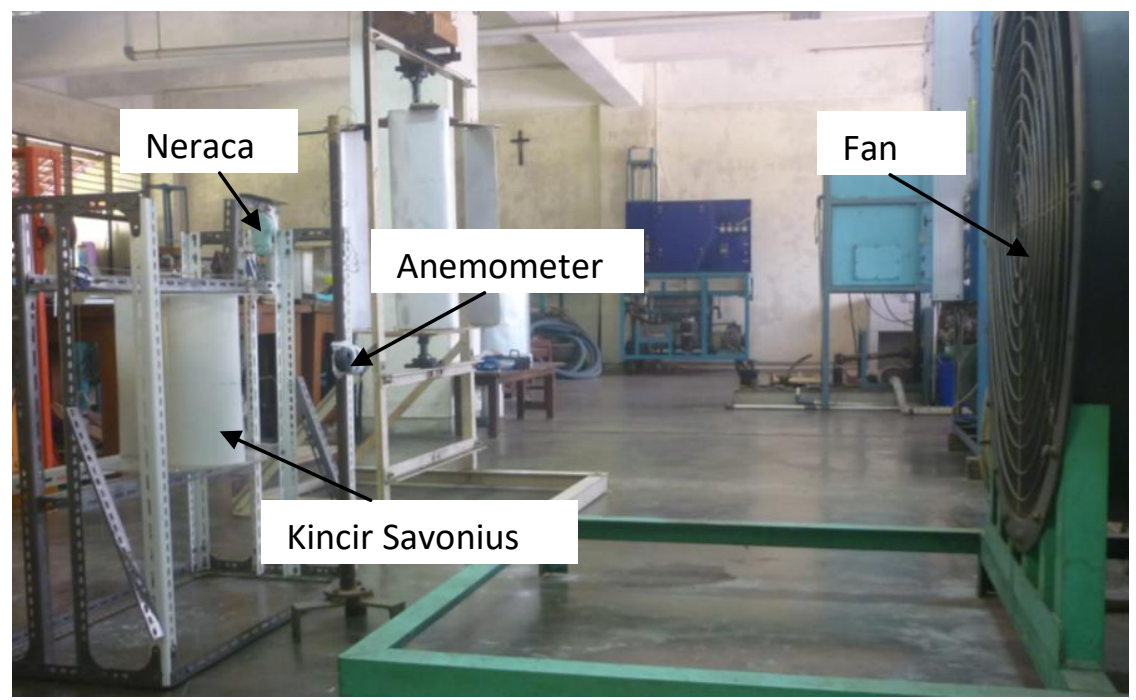

Gambar 4. Set up alat

Persamaan-persamaan dalam menentuan torsi output, daya input, daya output, tip speed ratio (tsr), koefisien daya dan koefisien torsi sebagai berikut. Adapun $\mathrm{F}=$ gaya pengereman, $\mathrm{r}=$ jarijari piringan, $\rho=$ massa jenis udara, $\mathrm{A}=$ luas penampang kincir, $\mathrm{V}=$ kecepatan angin, $\omega=$ kecepatan sudut kincir, $\mathrm{D}=$ diameter kincir.

Torsi output

$T=F . r$

Daya input

$$
P_{\text {in }}=\frac{1}{2} \rho A V^{3}
$$

Daya output

$$
P_{\text {out }}=T \omega
$$




$$
\omega=\frac{2 \pi n}{60}
$$

Koefisien daya

$$
C_{p}=\frac{P_{\text {out }}}{P}
$$

Koefisien torsi

$$
C_{t}=\frac{T}{0,5 \rho A V^{2} r}
$$

$\mathrm{Tsr}$

$$
\lambda=\frac{\omega r}{V}=\frac{\pi D n}{V}
$$

Pengujian dilakukan dengan kecepatan angin yang bervariasi. Kecepatan angin yang digunakan adalah $3 \mathrm{~m} / \mathrm{s}, 4 \mathrm{~m} / \mathrm{s}, 5 \mathrm{~m} / \mathrm{s}$ dan $6 \mathrm{~m} / \mathrm{s}$.

\section{Hasil dan Pembahasan}

Gambar 5 sampai dengan Gambar 8 memperlihatkan hubungan koefisien daya terhadap tsr pada kecepatan angin $3 \mathrm{~m} / \mathrm{s}, 4 \mathrm{~m} / \mathrm{s}, 5 \mathrm{~m} / \mathrm{s}$ dan $6 \mathrm{~m} / \mathrm{s}$. Koefisien daya tertinggi berada pada nilai tsr antara 0,7 - 1. Gambar 5 menunjukkan hubungan koefisien daya terhadap tsr pada kecepatan angin $3 \mathrm{~m} / \mathrm{s}$, dengan nilai tertinggi pada kincir angin Savonius dengan sudut guide vane $60^{\circ}$ sebesar $20 \%$. Hal ini terjadi karena aliran udara dibelokkan dengan sudutguide vane $60^{\circ}$ tepat mengenai sudu dorong sedang aliran pada sudu balik dibelokkan menjauhi sudu. Guide vane dengan sudut $30^{\circ}$ membuat aliran menuju kincir baik ke sudu dorong maupun sudu balik sama-sama besar, sehingga selisih gaya menjadi lebih kecil. Sebagai akibatnya koefisien daya bernilai rendah. Gambar 6 sampai Gambar 8 memperlihatkan hubungan koefisien daya terhadap tsr pada kecepatan angin $4 \mathrm{~m} / \mathrm{s}, 5 \mathrm{~m} / \mathrm{s}$ dan $6 \mathrm{~m} / \mathrm{s}$, dapat dilihat bahwa nilai tertinggi koefisien daya dimiliki oleh kincir dengan guide vane bersudut $45^{\circ}$. Nilai tertinggi pada penelitian ini diperoleh kincir dengan guide vane berudut $45^{\circ}$ sebesar $24 \%$ pada kecepatan angin $5 \mathrm{~m} / \mathrm{s}$, ditunjukkan pada Gambar 9. Pada kondisi ini kincir efektif dalam menerima aliran udara, yaitu ketepatan aliran mengenai sudu dorong dan sedikitnya aliran yang melewati celah antara kincir dengan guide vane. 


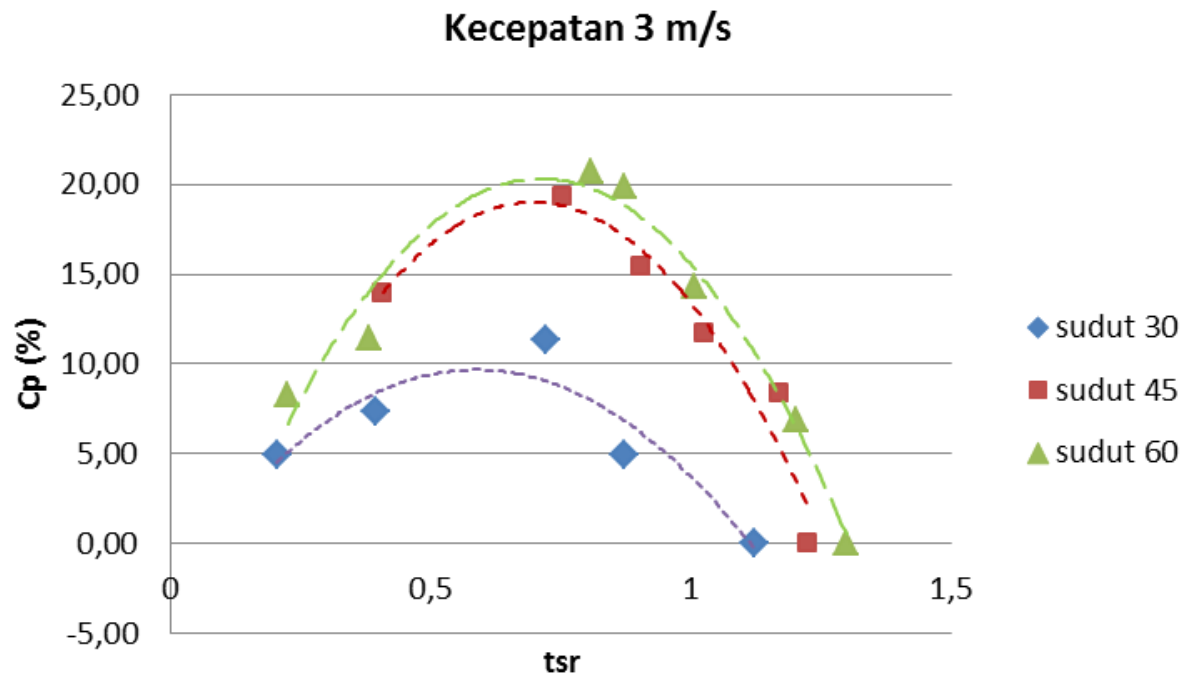

Gambar 5. Hubungan koefisien daya dengan tsr pada kecepatan angin $3 \mathrm{~m} / \mathrm{s}$

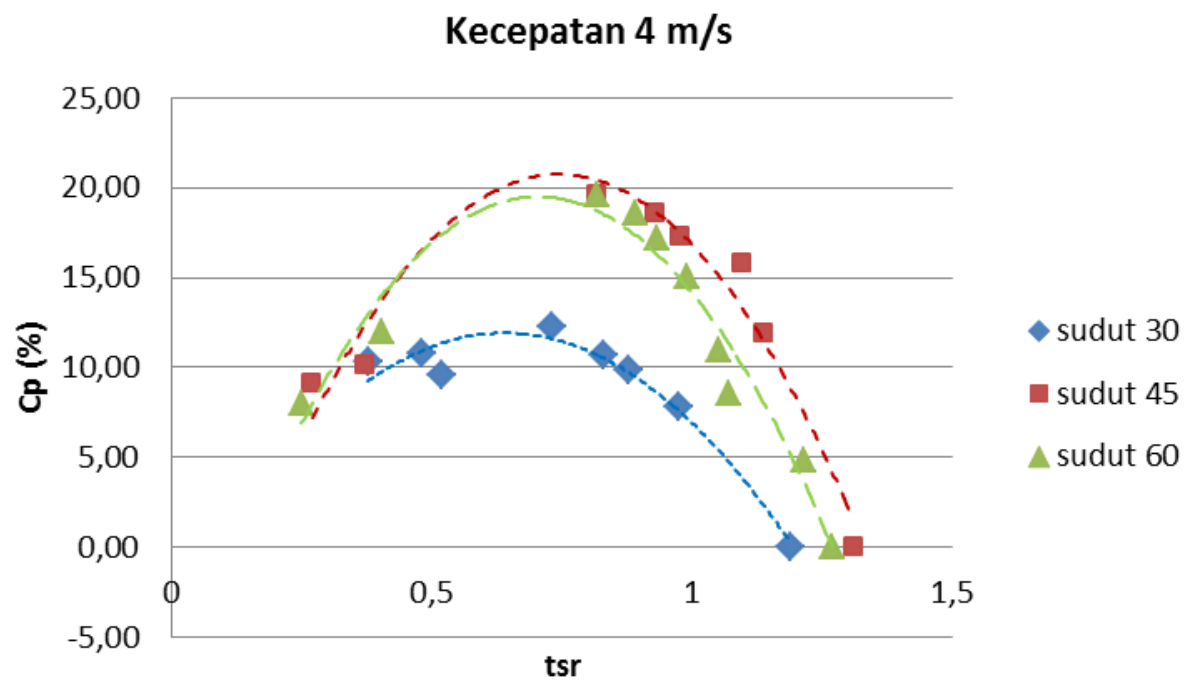

Gambar 6. Hubungan koefisien daya dengan tsr pada kecepatan angin $4 \mathrm{~m} / \mathrm{s}$ 


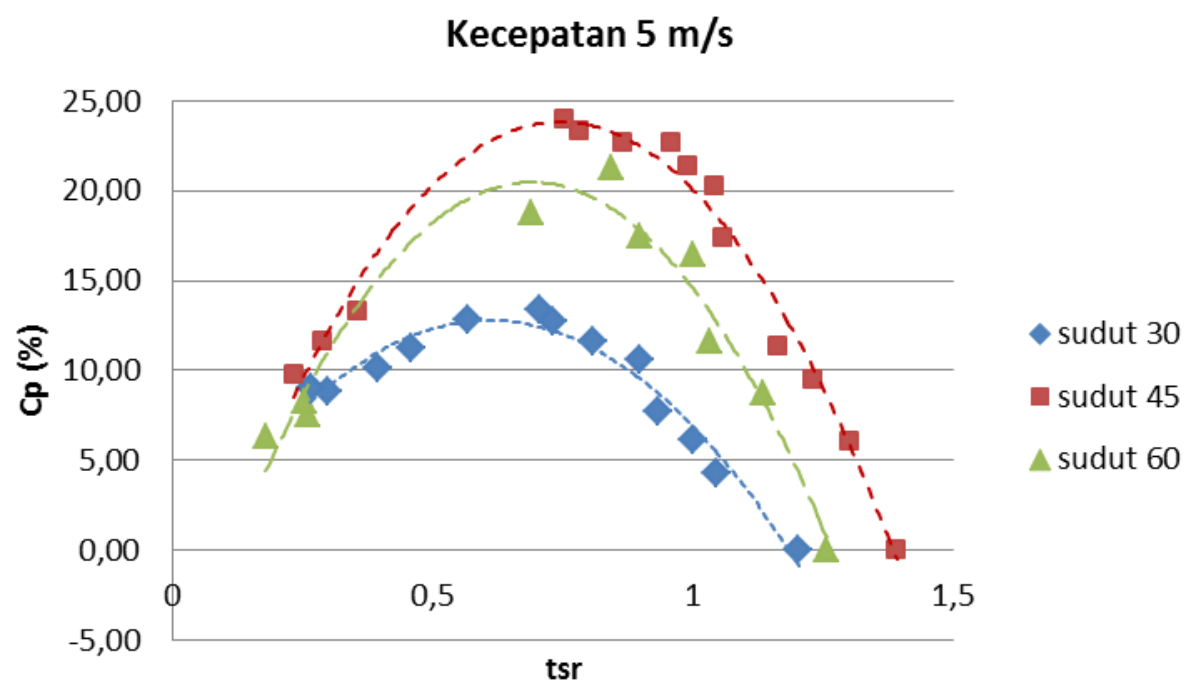

Gambar 7. Hubungan koefisien daya dengan tsr pada kecepatan angin $5 \mathrm{~m} / \mathrm{s}$

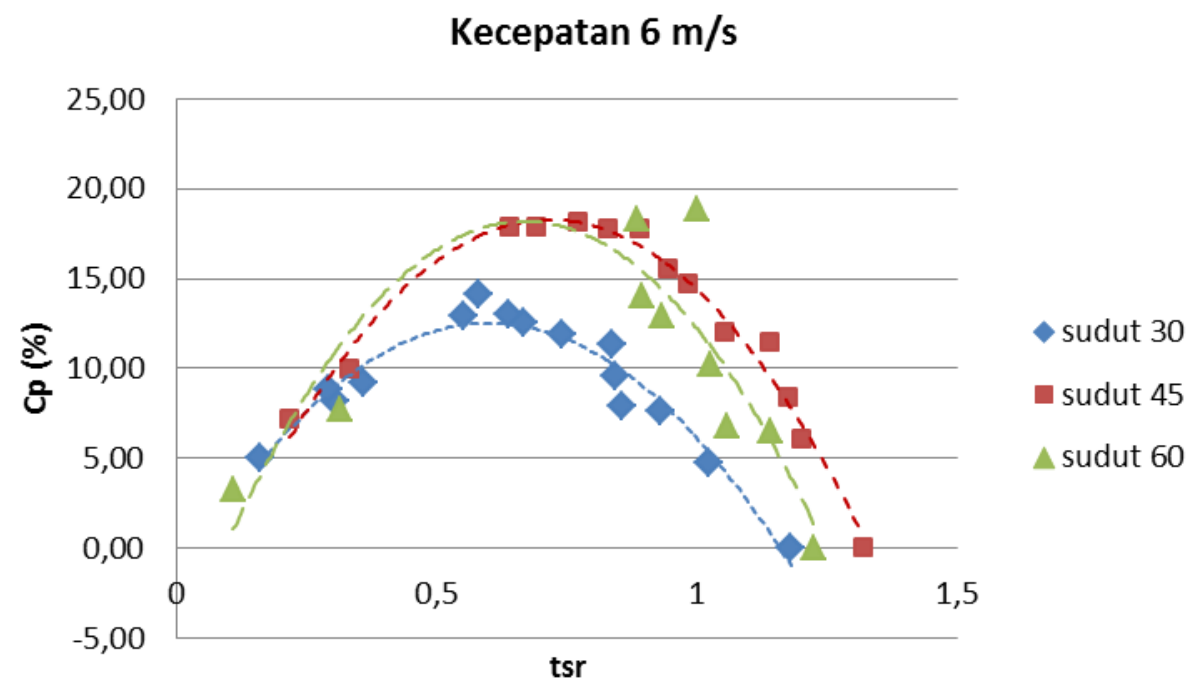

Gambar 8. Hubungan koefisien daya dengan tsr pada kecepatan angin $6 \mathrm{~m} / \mathrm{s}$ 


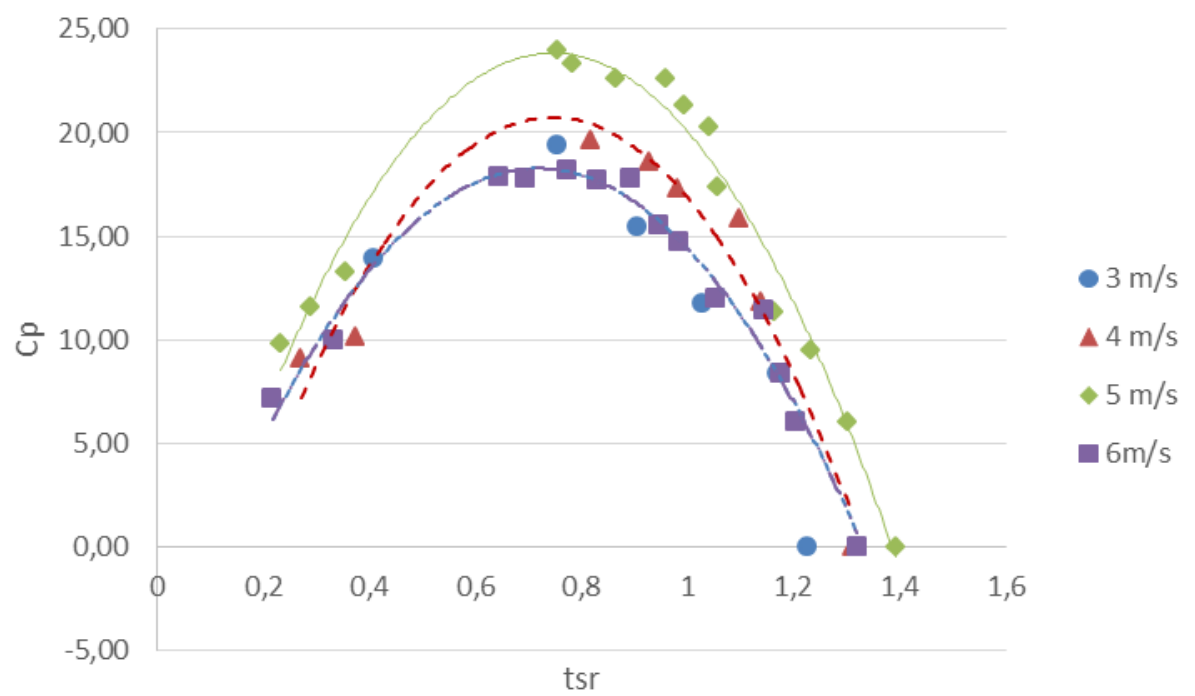

Gambar 9. Hubungan koefisien daya dengan tsr pada guide vane $45^{\circ}$

Hubungan koefisien torsi terhadap putaran ditunjukkan pada Gambar 10 - 14. Koefisien torsi menurun linier dengan bertambahnya putaran kerja kincir. Kincir dengan guide vane bersudut $30^{\circ}$ pada kecepatan angin berapapun nilai koefisien torsi selalu lebih rendah dibandingkan dengan kondisi yang lain. Pada kecepatan angin $3 \mathrm{~m} / \mathrm{s}$ dan putaran di bawah 125 rpm kincir dengan guide vane bersudut $45^{\circ}$ mempunyai nilai lebih tinggi dibandingkan kincir dengan guide vane bersudut $60^{\circ}$. Secara umum kincir dengan guide vane bersudut $45^{\circ}$ memiliki nilai yang lebih tinggi dibandingkan kincir dengan guide vane $30^{\circ}$ dan $60^{\circ}$.

Gambar 14 memperlihatkan hubungan koefisien daya terhadap putaran kincir pada kincir dengan guide vane bersudut $45^{\circ}$. Koefisien torsi tertinggi dibawah putaran $250 \mathrm{rpm}$ dimiliki oleh kincir saat bekerja pada kecepatan angin $5 \mathrm{~m} / \mathrm{s}$, selebihnya bila kincir bekerja dengan kecepatan angin $6 \mathrm{~m} / \mathrm{s}$. Koefisien torsi tertinggi senilai $20 \mathrm{Nm}$ dimiliki oleh kincir dengan guide vane bersudut $45^{\circ}$ pada kecepatan angin $5 \mathrm{~m} / \mathrm{s}$.

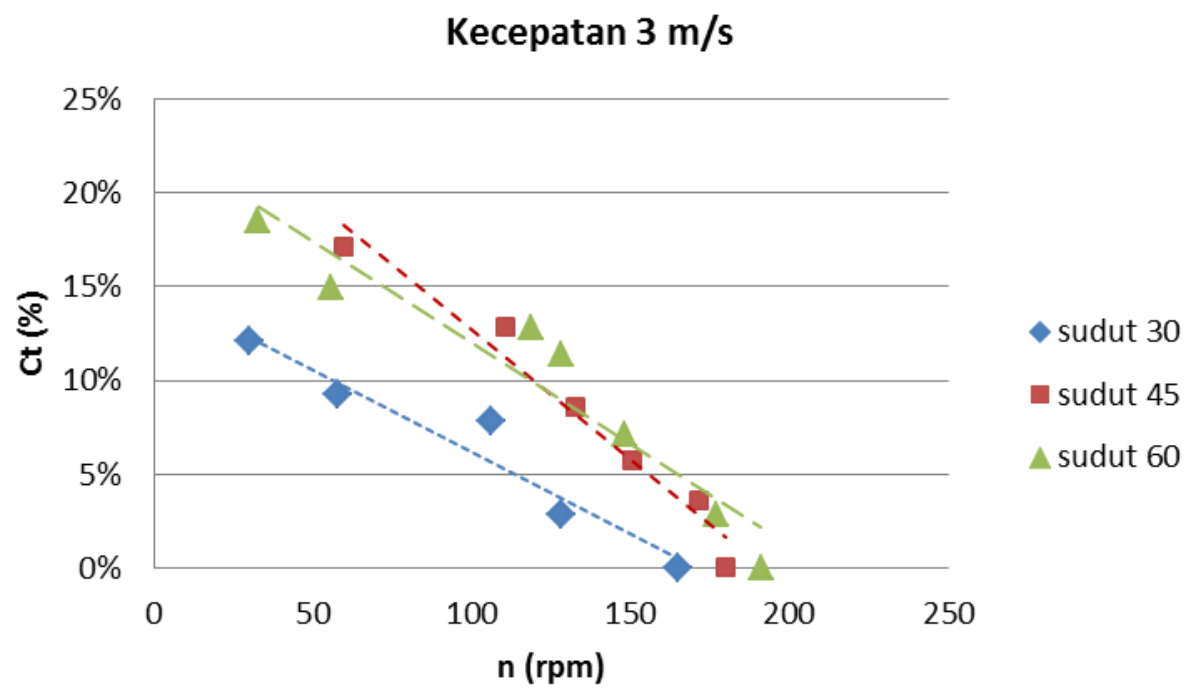


Gambar 10. Hubungan koefisien torsi dengan putaran (n) pada kecepatan angin $3 \mathrm{~m} / \mathrm{s}$

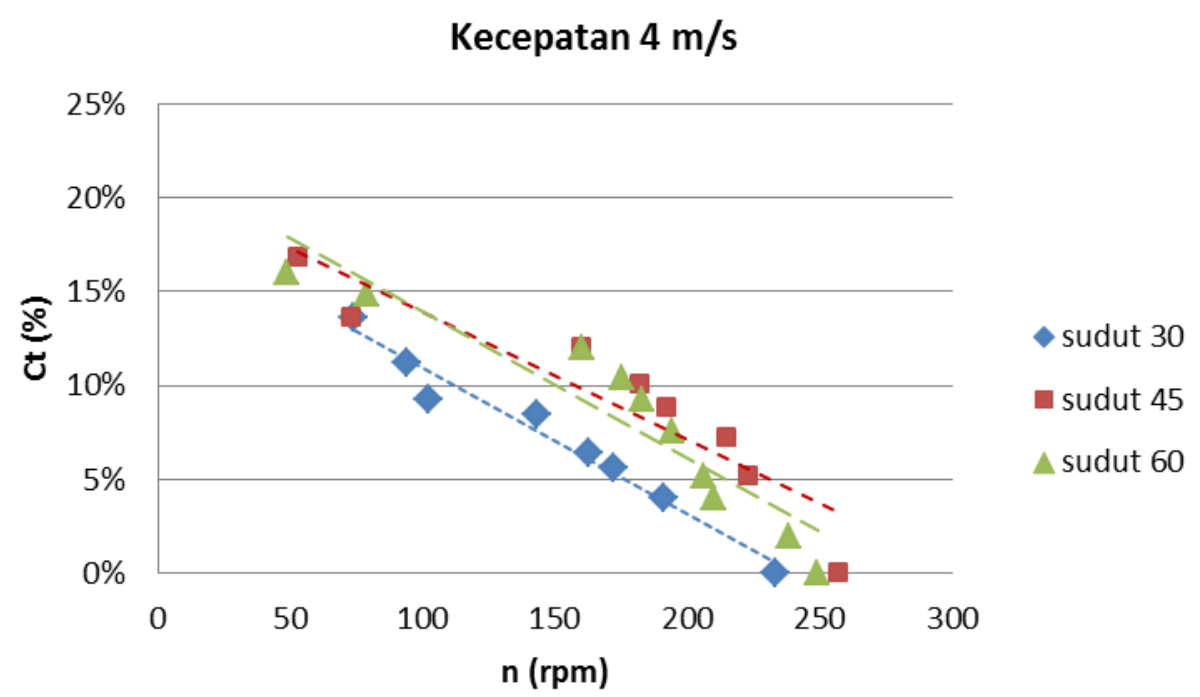

Gambar 11. Hubungan koefisien torsi dengan putaran (n) pada kecepatan angin $4 \mathrm{~m} / \mathrm{s}$

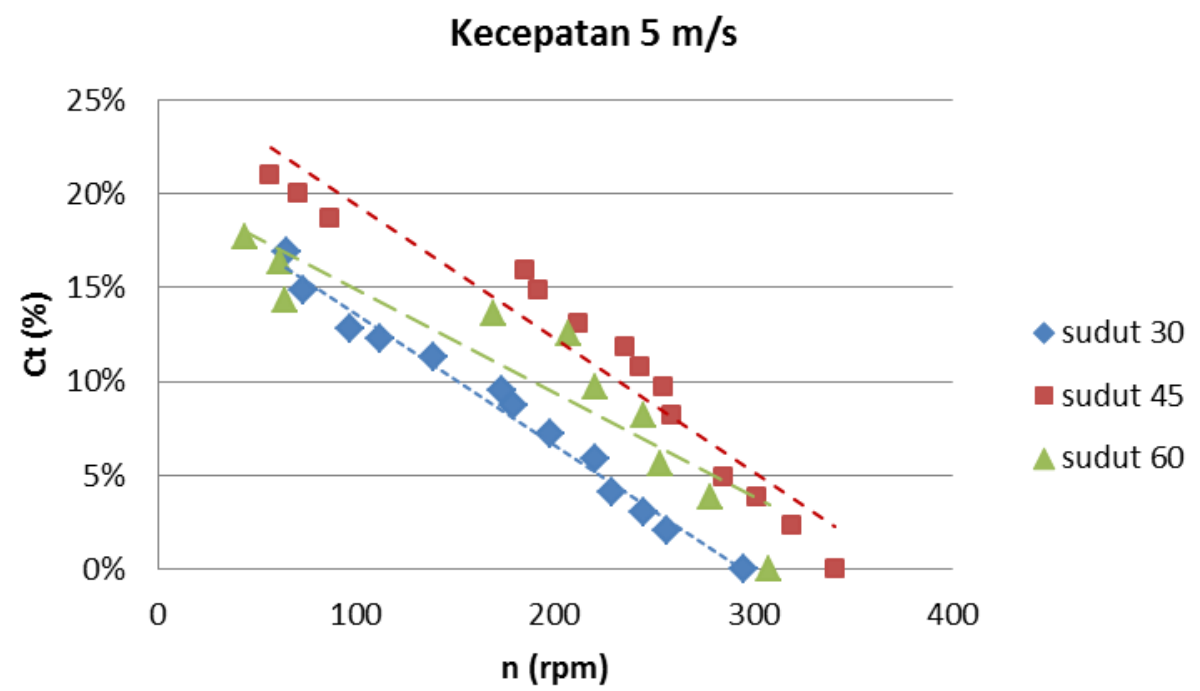

Gambar 12. Hubungan koefisien torsi dengan putaran (n) pada kecepatan angin $5 \mathrm{~m} / \mathrm{s}$ 


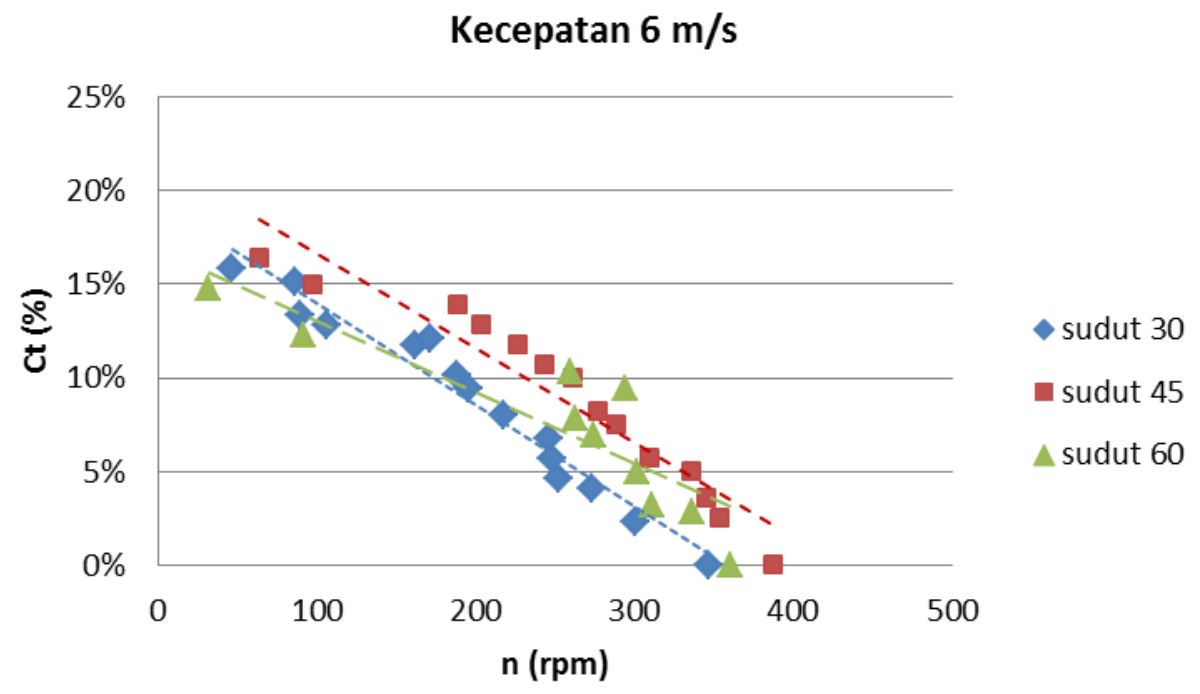

Gambar 13. Hubungan koefisien torsi dengan putaran (n) pada kecepatan angin $6 \mathrm{~m} / \mathrm{s}$

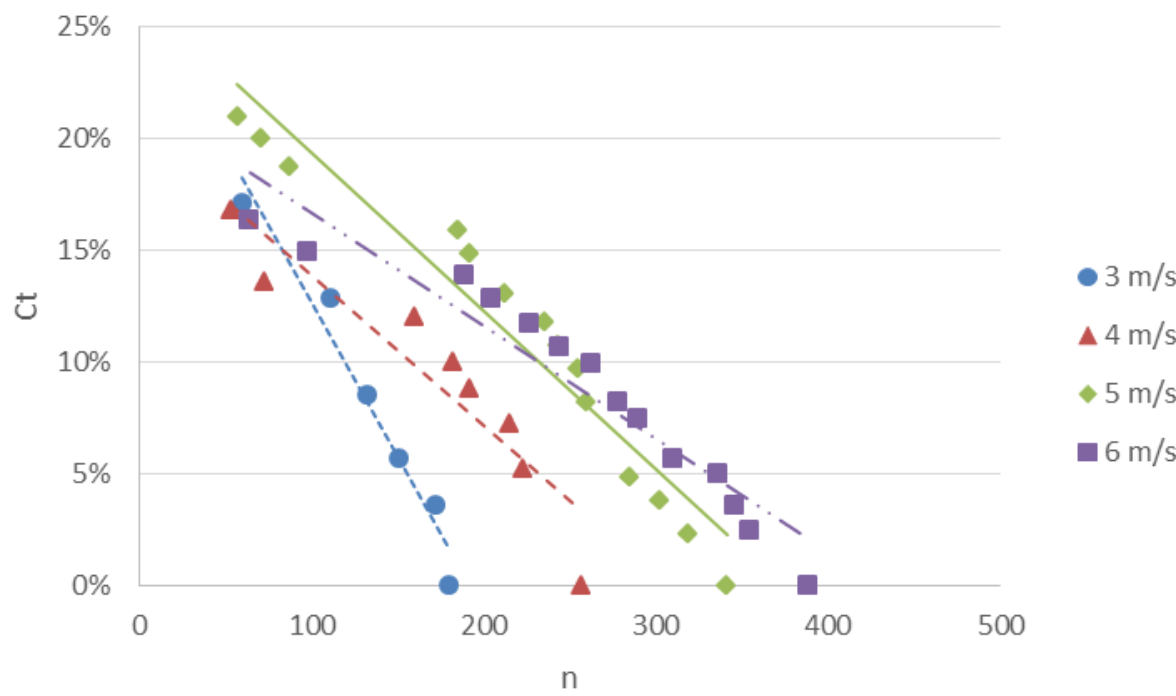

Gambar 14. Hubungan koefisien torsi dengan putaran (n) pada kincir dengan guide vane bersudut $45^{\circ}$

\section{Kesimpulan}

Dari pembahasan diatas, bahwa kincir angin Savonius dengan Guide vane bersudut $30^{\circ}$, $45^{\circ}$ dan $60^{\circ}$ dapat disimpulkan koefisien daya tertinggi diperoleh pada saat tsr sebesar $0,7-1$. Kincir dengan guide vane bersudut $45^{\circ}$ pada kecepatan angin $5 \mathrm{~m} / \mathrm{s}$ memiliki nilai koefisien daya tertinggi sebesar $24 \%$. Sedang koefisien torsi tertinggi pada kincir dengan guide vane bersudut $45^{\circ}$ pada kecepatan angin $5 \mathrm{~m} / \mathrm{s}$ dan putaran $100 \mathrm{rpm}$ sebesar $20 \%$ 


\section{Ucapan Terima kasih}

Terima kasih kepada LPPM Universitas Sanata Dharma Yogyakarta yang telah membiayai pelaksanaan penelitian ini.

\section{Daftar Pustaka}

[1] Johnson, G. L. (2001). Wind Energy Systems. Manhattan: Kansas State University.

[2] Fujisawa, N. \& Gotoh, F. (1992). Visualization Study of the Flow in and around a Savonius Rotor. Experiments in Fluids. 12.

[3] Altan, B. D., \& Atilgan, M. (2012, February 6). A Study on Increasing the Performance of Savonius Wind Rotors. Journal of Mechanical Science and Technology, 26(5), 1493-1499.

[4] Altan, B. D., \& At1lgan, M. (2008, October 5). An Experimental and Numerical Study on the Improvement of the Performance of Savonius Wind Rotor. Energy Conversion and Management, 49, 3425-3432.

[5] Altan, B. D., Atılgan, M., \& Özdamar, A. (2008, June 10). An Experimental Study on Improvement of a Savonius Rotor Performance with Curtaining. Experimental Thermal and Fluid Science, 32, 1673-1678.

[6] Sugiharto, B., Soeparman, S., Widhiyanuriyawan, D., \& Wahyudi, S. (2016). Performances of Savonius Rotor with Addition Guide Vanes. International Journal of Renewable Energy Research, 6(4), 1336-1341. 